\author{
(online) $=$ ISSN $2285-3642$ \\ ISSN-L = 2285 - 3642 \\ Journal of Economic Development, Environment and People \\ Volume 3, Issue 3, 2014 \\ URL: http://jedep.spiruharet.ro \\ e-mail: office jedep@spiruharet.ro
}

\title{
Intellectual Capital in Enterprises and a Model Study in an Industrial Zone
}

\author{
Selcuk Kendirli ${ }^{1}$, Sabiha Kilic and Hulya Cagiran Kendirli ${ }^{\text {[ }}$ \\ 1 Hitit University FEAS Banking and Finance
}

\begin{abstract}
The study mainly consists of two parts. The first part includes theoretical knowledge; the second part includes application-oriented information.

In the theoretical part of the study, intellectual capital and SMEs are emphasized in general. In the application-oriented part of the study, a field research will be done for Corum SME. In this study, the demographic structure of Corum SMEs, intellectual capital structure and financial performance of this structure will be evaluated. The resulting data will be analyzed in this context. The businesses operating in the Organized Industrial Zone of Corum and those matching the definition of SME will be considered within the research scope. Surveys will be applied by interviewers face to face and each survey will be evaluated individually. After the evaluation, a model will be proposed.

The aim of our study is to investigate the relationship between components of intellectual capital in SMES and business performance. For this reason, a survey will be conducted for SMEs. Since the results of the study will be shared with scientific circles and the public, they will prove to be guiding for Çorum SMEs.
\end{abstract}

Keywords: SME, Intellectual Capital, Human Capital, Structural Capital, Relational Capital, Çorum SMEs

JEL Codes: M20, M21

\section{Introduction}

In today's commercial environment where global competition is experienced intensely, the success rates of SMEs have been started to be increasingly linked with intellectual capital assets. Accordingly, to develop their intellectual capital SMEs should achieve to activate the basic capabilities and features which are expanding the mind, encouraging innovation and ensuring the integrity. Therefore, it can be expressed that, intellectual assets such as productivity, human resources, behavior, education, technological skills, managerial skills, innovation and creativity in marketing activities, cooperation and coordination have effect on SME's performance.

Intellectual capital includes legally applicable intellectual asset rights (patents, trademarks, copyright, etc.) and both tangible and intangible aspects of intellectual knowledge which a business has accumulated

Corresponding author E-mail address: selcukkendirli@hitit.edu.tr 


\author{
(online) $=$ ISSN $2285-3642$ \\ ISSN-L = 2285-3642 \\ Journal of Economic Development, Environment and People \\ Volume 3, Issue 3, 2014 \\ URL: $\underline{\text { http://jedep.spiruharet.ro }}$ \\ e-mail: office jedep@spiruharet.ro
}

and developed over the years (Yu, 2001). The value of the business's intellectual capital assets is the difference between the book value of the businesses and the market value.

Until the 1980s, management theory, as a basis for understanding of competitive advantage has focused on business environment (Roos and Roos, 1997). According to Porter (1980), five structural variables affect the company's competitive edge and profitability: supplier power, threat of new market entrants, the threat of substitutes, industry competition and the power of the recipient. According to this model; a business's profit potential is determined out by entrepreneurs' business industry characteristics However, most of the company's resources are heterogeneous and cannot be easily imitated. These resources serve as potential sources of competitive advantage. This resource-based perspective on competitive advantage has a significant impact on environmental factors (Moon and Kym, 2006).

Basic skills are usually considered as information which is about the intangible values of the organization and forms the basis of the competitive advantage (is accepted). This basic skill contains information technology (Mata, Fuerst and Barney, 1995; Powell, 1997), human resources management (Lado and Wilson, 1994) and organizational culture (Fiol, 1991) contains nudes.

While many researchers accept the intellectual capital as a basic element and source of competition; managers and administrators (authorized holder) have difficulty in defining and evaluating it. According to Handy (1990), most of the managers use only $20 \%$ of the organizations information. However they do not benefit from the remaining $80 \%$ part with which they can provide better evaluation, management and communication. Since the 1980s, as a result of the increasing importance of the intellectual capital evaluation, researchers have proposed some intellectual capital assessment tools (Moon and Kym, 2006).

The process called knowledge economy and created by development waves in information and communication technology, has made information the most important economic power in enterprises. Which have the vision and mission of intellectual capital (Pirtini, 2004:13). Especially for SMEs; to develop products and services, strengthen and make valuable the intellectual property, adapt to better rapid changes in the market and continue innovation knowledge management carries great importance. Today with the development of knowledge-based global economy, finding, improving, maintaining and sharing intellectual capital has become one of the most important economic functions of SMEs. (Stewart, 1997:13).

\title{
2. Intellectual Capital
}

Concept of "intellectual" has been used for the first time in the late 1960s. In 1969 economist John Kenneth Galbraith wrote in a letter to Polish economist Michal Kalecki, "I wonder if you realize how much those of us in the world around have owed to the intellectual capital you have provided over these past decades." He introduced the concepts into the literature by using this expression (Erkal, 2006:42).

Galbraith has been associating individual intellectual unit with the individual performance. But in previous years, Peter Drucker coined the term "knowledge worker" (1995). According to Drucker knowledge takes place across geographic boundaries and in the center of key resources and intellectual capital it is a resource that adds value by creating competitive advantage for enterprises in the marketing. (Drucker, 59-60)

The concept of intellectual capital didn't come to the agenda for many years after the 1960s, and didn't capture attention among the other organizational topics. As a result of the appearance of new intangible 


\author{
(online) $=$ ISSN $2285-3642$ \\ ISSN-L = $2285-3642$ \\ Journal of Economic Development, Environment and People \\ Volume 3, Issue 3, 2014 \\ URL: http://jedep.spiruharet.ro \\ e-mail: office jedep@spiruharet.ro
}

elements which were related to the development of technologies that took place in 1980's, new economic structure so-called "knowledge economy" came on the agenda. (Erkal, 2006:41).

In search of new values for organizational creativity and to provide answers to questions of how to use resources more efficiently and more effectively and how to achieve better results with existing resources, the subject was re-opened for discussion in Japan during the1980s, (Kanıbir, 2004: 78).

Japanese Hiroyuki Itami's book "Invisible Assets" written in 1980 which was about the impact of virtual assets on Japanese companies and their management didn't draw much interest initially, but by 1987 his book was translated into English, and has been used in studies on intellectual capital (Itami, 1987).

Sveiby, pioneered on the development of appropriate accounting methods for intangible assets, expressing the necessity of assessing the human capital. All the work done in 1989 was collected in his book "Invisible Balance Sheet" and it suggested a theory for the measurement of knowledge capital. In 1993, Swedish Service Sector Council decided to standardize Sveiby's theory on Annual Reporting and it had been the first standard that was made applicable. Sveiby, has been analyzing intellectual capital within the scope of intangible assets under three sets of external structure, internal structure and individual competence;

External structure includes brands, customers, supplier relationships; internal structure includes management of an organization, legal structure, functioning systems, approach attitude and $R$ \& $D$ activities; the individual competence includes education and experience of study. (Edvinsson, 1998). Leif Edvinsson affected by the ideas of Sveiby renamed, intangible assets as intellectual capital (Yıldız ve Tenekecioğlu, 2004: 580-581).

Edvinsson (1997), determines intellectual capital as a "knowledge, that ensures advantage in market, in enterprises, experience, organizational technology, customer relationships and professional skills", and divides it into two main groups as human capital and structural capital. In his article "Your Company's Most Valuable Asset: Intellectual Capital", written in 1994, Stewart describes Intellectual Capital as "knowledge and know-how unit of individual which is the source of inventor ship and innovation" and "talent, skill and expertise that embedded in human brain" (Stewart, 1994; 30).

In addition, according to Stewart (1997), the intellectual capital includes the processes of organization, technologies, patents, ability of employees and the information about customers, suppliers and other related parties (Stewart, 1997:7).

Barney who studied Intellectual Capital in 1991, 1996 and 2002, classified business resources under four groups: financial capital, physical capital, human capital and organizational capital. According to Barney $(1991,1996)$, financial capital includes all financial resources. Physical capital is the existing technology of the enterprise. Human capital, is related to levels of training, experience, justice, knowledge, communication and understanding of enterprise employees. Organizational capital includes formal and informal structures of an enterprise.

In addition, organizational capital also includes: the business culture, business reputation, factors such as relationship of the operating with other businesses and between their own groups. (Barney, 1996, 2002).

Intellectual capital in the pyramid in Figure 1, include the rights of tangible assets, intangible assets and intellectual assets. This pyramid is very important. Namely, the knowledge that enterprises possess, includes business relationships involving the use of outsourcing, telecommunication, the rapid 


\author{
(online) = ISSN $2285-3642$ \\ ISSN-L = $2285-3642$ \\ Journal of Economic Development, Environment and People \\ Volume 3, Issue 3, 2014 \\ URL: http://jedep.spiruharet.ro \\ e-mail: office jedep@spiruharet.ro
}

development in technology, application like attitude towards common risks involved in the global market. (Rose, 2000).

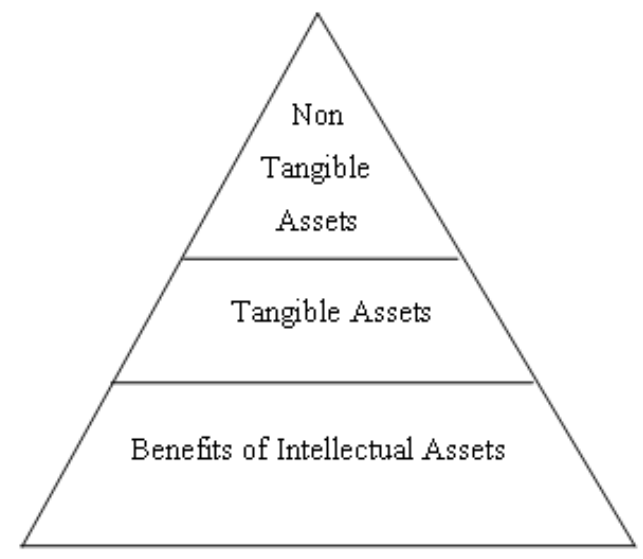

Fig. 1: Pyramid of Intellectual Capital.

Source: Adapted from Brown Jr. and others, 2005:35.

Analyzing the pyramid of intellectual capital we can see the intangible assets at the top of it. These assets include employee's knowledge and skills, innovative ideas about products and marketing strategies, relationship with customers and suppliers. The success of intangible assets, may be affected by some activities and instruments such as marketing, purchasing, human resources, engineering and manufacturing, commercial cooperation and earnings of enterprise. It can ensure the financial capacity and human capital of the business. Though they were not having a physical form, intangible assets are as valuable as tangible assets and are legally enforceable intellectual property. Protection of intangible assets is very difficult and depends largely on human beings of the business.

For success in today's business world, to manage intangible assets as strategic instruments has become an important requirement. Tangible assets are located in the middle of the pyramid. Tangible assets can be carried into or out of business, either physically or in an electronic way. These assets contain all the sources of information as well as databases and operating records, at the same time they contain past information and documented procedures that include the structure of current employment experience and capability. The success of these assets may be affected by purchasing, trade cooperation and earnings and engineering and by activities and tools such as manufacturing and information technology of the enterprise. At the bottom of the pyramid is replaced legally enforceable intellectual property. These contain such rights as patents, trademarks, copyrights, trade secrets and licenses.

Activities and instruments, such as commercial co-operation and benefits, engineering and manufacturing, information technology, legal staff, has an impact on success of the rights of intellectual assets. Legally enforceable intellectual property and enterprises appertaining to tangible and intangible assets can be faced with such difficulties as intellectual capital theft, trademark piracy, identity theft and false claims, inadequate law and global inconsistency (Brown Jr., 2005). 


\author{
(online) $=$ ISSN $2285-3642$ \\ ISSN-L = 2285-3642 \\ Journal of Economic Development, Environment and People \\ Volume 3, Issue 3, 2014 \\ URL: $\underline{\text { http://jedep.spiruharet.ro }}$ \\ e-mail: office jedep@spiruharet.ro
}

\title{
3. Conceptual Framework Of Intellectual Capital And A Model Study In An Industrial Zone -Çorum Industrial Zone
}

According to resource-based perspective non-operating, according to resources of industry internal resources are considered as the basic assets for sustainable competitive advantage. These internally generated resources cover intangible assets and core competencies. (Barney,1986, Wernerfelt, 1984). The concept of core competency is often used instead of the concepts like absorptive capacity (Cohen and Levinthal, 1990), strategic assets (Amit and Schoemaker, 1993), the core capability (Zander and Kogut, 1995) and intangible assets (Hall, 1992). Core competencies are considered as knowledge about intangible value of organization which usually forms the bases of competitive advantage (is accepted). These core competencies include information technology (Mata, Fuerst and Barney, 1995; Powell, 1997), human resources management (Lado and Wilson, 1994) and organizational culture (Fiol, 1991).

Andriessen (2004) made the necessary explanation about three basic questions (What, Why and How?) which should be taken into account for evaluation of intellectual capital. The "What" question, is related to the classification scheme content of intellectual capital. The "Why" question is related to causes of assessment or measurement of intellectual capital. Finally, the "How" question is related with evaluation of variety of intellectual capital and measuring approaches.

Intellectual capital is defined according two approaches. The first approach is thought to occur in three dimensions of intellectual capital: human capital, structural capital and relational capital. There is several proposed assessment for each measure (Moon and Kym, 2006). Sveiby (1997:10), defined human capital, as "an ability which has operations in wide variety of positions in order to create tangible and intangible assets", structural capital as "patents, concepts, models, computer and management systems" and relational capital as "relationship with customers and suppliers". Edvinsson and Malone (1997), Brooking (1996), Sveiby (1997), Bontis and others (2000) adopt this approach. The second approach, Saint-Onge (1996) and Knight (1999) explain with examples. The authors define the bases of intellectual capital dimensions, but didn't find any proposal to measure them (Moon and Kym, 2006).

In this study, intellectual capital dimension evaluation in the sphere of suggestions of the researchers which take the first approach as a base and the impact of this dimension on achievement level and business performance of intellectual capital is being analyzed.

The researchers conducted in the scope of the first approach, define each basis of intellectual capital dimension and an index is obtained from each dimension. Together with this approach, intellectual capital is defined perfectly well and the best measure of value is modified for intellectual capital. Different measures of value were used for human capital in many research works. (Moon and Kym,2006).

These measures can be expressed as annual staff turnover rate, leading indicators, education levels of managers (Edvinsson and Malone, 1997), technical information, education, cultural differences, workrelated knowledge, professional assessments, psychometric evaluation (Brooking, 1996) consecutive training programs, competency level of ideas, program planning skills, do without thinking, to reduce underemployment, employees give it their all (Bontis et al., 2000), the ability turnover, change in the value added per employee, change in the rate of working, growth in average of professional experience (Sveiby, 1997). In this study the relationship between intellectual capital level of success that is affected by intellectual capital dimension and business performance are evaluated. 


\author{
(online) $=$ ISSN $2285-3642$ \\ ISSN-L = $2285-3642$ \\ Journal of Economic Development, Environment and People \\ Volume 3, Issue 3, 2014 \\ URL: $\underline{\text { http://jedep.spiruharet.ro }}$ \\ e-mail: office jedep@spiruharet.ro
}

In this sense, an indirect relationship between business performance and human capital can be tested with hypothesis developed below:

H1: The more business performance increases the more success level of Intellectual capital affected by human capital increases.

Lost customers, the number of consumer visits, satisfied customer index, days spent visiting customers, per employee education, employee satisfaction index, administrative error rate, $R$ \& $D$ expenditures for administrative expenses, IT expenses per employee (Edvinsson and Malone, 1997), management philosophy, corporation culture, leadership style, knowledge base, expert networks and teams, managing process, patents, design rights, trademarks, service marks, copyrights, trade dress (Brooking , 1996), the lowest cost per transaction, the development of the best ideas in the industry, improving the costs per revenue (Bontis et al., 2000) takes place among measures of value which can be used in structural capital assessment that took place among the intellectual capital dimensions can be helpful in assessing the performance of businesses.

In this sense, an indirect relationship between business performance and structural capital can be tested with the following developed hypothesis:

H2: The more business performance increases the more success level of Intellectual capital affected by structural capital increases.

Relational capital which is another dimension of intellectual capital, also affects directly the level of success of intellectual capital, and thus business performance. Brands, consumer loyalty, distribution channels, licensing agreements, appropriate contracts, commercial cooperation, customer depth and width (Brooking, 1996), in general, satisfied customers, reduce time to resolve the problem, improving market share, the highest market share, long-lasting relationships (Bontis et al., 2000). In this sense, an indirect relationship between business performance and relational capital can be tested with the following developed hypothesis:

H3: The more business performance increases the more success level of Intellectual Capital affected by relational capital increases

H4: The more success level of Intellectual capital, affected by customer capital, increases, the more business performance increases.

In this context, a model that can be created about the impact of intellectual capital on business performance can be shown as follows. 


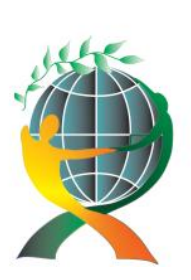

\author{
(online) $=$ ISSN $2285-3642$ \\ ISSN-L = 2285 - 3642 \\ Journal of Economic Development, Environment and People \\ Volume 3, Issue 3, 2014 \\ URL: http://jedep.spiruharet.ro \\ e-mail: office jedep@spiruharet.ro
}

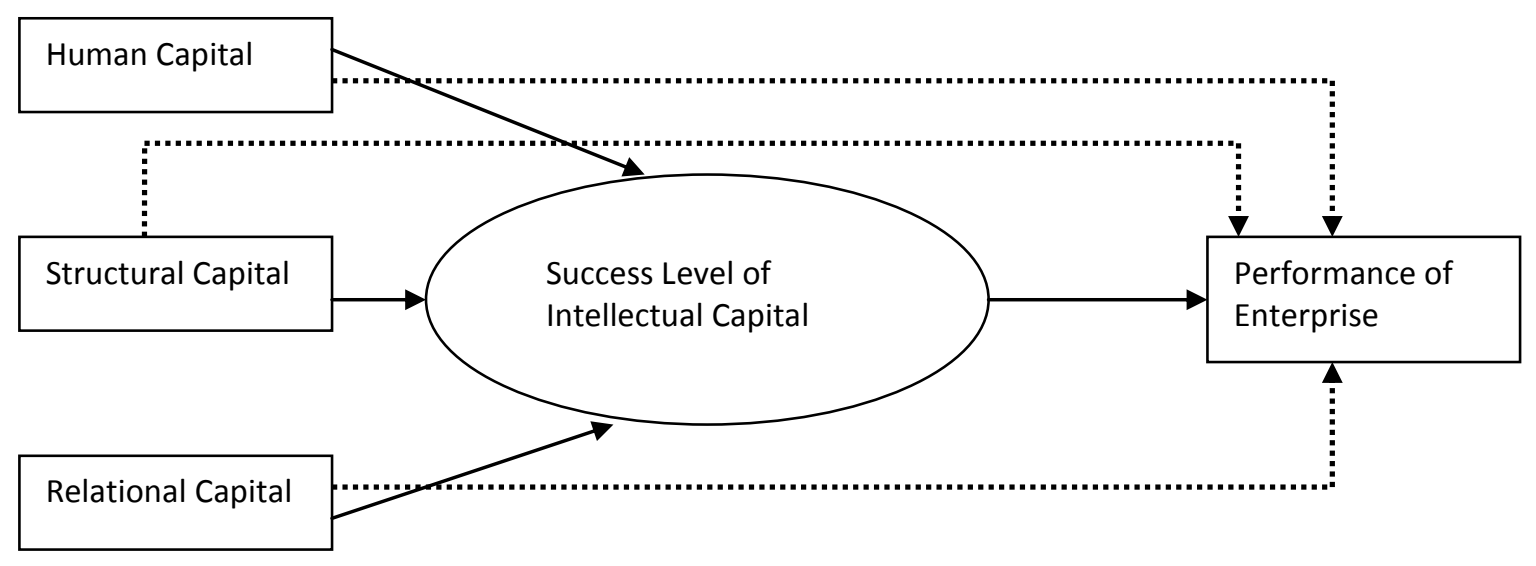

Fig. 2: Model of Research: A Study in Corum Industrial Zone

\title{
Purpose
}

The purpose of the survey is to investigate the intellectual capital in SMEs operating in the Corum Organized Industrial Zone and the impacts of the intellectual capital on the business performance.

\section{Assumptions}

The assumptions of the study are followings;

- $\quad$ The information given by the enterprises reflects the reality.

- It is assumed that in the enterprises taken in to the working scope, the survey questions were correctly detected and they were answered according to that.

- The business performance increases as the success level of the intellectual capital affected by human capital increases.

- Business performance increases as the success level of the intellectual capital affected by structural capital increases.

- $\quad$ Business performance increases as the success level of the intellectual capital affected by relational capital increases.

\section{Analysis of Data and Findings}

The raw data obtained as a result of the survey technique was evaluated statistically. In analyzing the data, percentage, frequency, mean, median and mode were used for descriptive statistics.

\section{Descriptive Statistics for Research Model.}

From descriptive statistics of variables related to the characteristics of the surveyed enterprises, the following distributions are used: percentage, frequency, mean, median and mode. 
(online) $=$ ISSN $2285-3642$

ISSN-L = $2285-3642$

Journal of Economic Development, Environment and People

Volume 3, Issue 3, 2014

URL: http://jedep.spiruharet.ro

e-mail: office jedep@spiruharet.ro

Table 1: Characteristics of enterprises

\begin{tabular}{|c|c|c|c|c|c|}
\hline The number of employees employed in the enterprise & $\mathbf{n}$ & $\%$ & Mean & Median & Mod \\
\hline $1-9$ & 15 & 24.2 & 1.95 & 2.00 & 2.00 \\
\hline $10-49$ & 36 & 58.1 & 1.95 & 2.00 & 2.00 \\
\hline $50-250$ & 10 & 16.1 & 1.95 & 2.00 & 2.00 \\
\hline $250+$ & 1 & 1.6 & 1.95 & 2.00 & 2.00 \\
\hline Total & 62 & 100.0 & & & \\
\hline The age of enterprise & $\mathbf{n}$ & $\%$ & Mean & Median & Mod \\
\hline less than a year & - & - & - & - & - \\
\hline 2-7 year & 15 & 24.2 & 4.11 & 4.00 & 4.00 \\
\hline $8-13$ year & 8 & 12.9 & 4.11 & 4.00 & 4.00 \\
\hline 14-19 year & 11 & 17.7 & 4.11 & 4.00 & 4.00 \\
\hline 20-25 year & 11 & 17.7 & 4.11 & 4.00 & 4.00 \\
\hline $25+$ & 17 & 27.4 & 4.11 & 4.00 & 4.00 \\
\hline Total & 62 & 100.0 & & & \\
\hline The number of patents the enterprise possesses & $\mathbf{n}$ & $\%$ & Mean & Median & Mod \\
\hline not any & 25 & 40.3 & 1.74 & 2.00 & 2.00 \\
\hline $1-3$ & 30 & 48.4 & 1.74 & 2.00 & 2.00 \\
\hline $4-6$ & 5 & 8.1 & 1.74 & 2.00 & 2.00 \\
\hline $7-9$ & 2 & 3.2 & 1.74 & 2.00 & 2.00 \\
\hline $10+$ & - & - & - & - & - \\
\hline Total & 62 & 100.0 & & & \\
\hline The amount of $R \&$ \& investments & $\mathbf{n}$ & $\%$ & Mean & Median & Mod \\
\hline less than 5000.00 & 58 & 93.5 & 1.18 & 1.00 & 1.00 \\
\hline $5.000 .00-20.000 .00 \mathrm{TL}$ & 1 & 1.6 & 1.18 & 1.00 & 1.00 \\
\hline $21.000 .00-50.000 .00 \mathrm{TL}$ & - & - & - & - & - \\
\hline $51.000 .00-100.000 .00 \mathrm{TL}$ & 2 & 3.2 & 1.18 & 1.00 & 1.00 \\
\hline $100.000 .00 \mathrm{TL}+$ & 1 & 1.6 & 1.18 & 1.00 & 1.00 \\
\hline Total & 62 & 100.0 & & & \\
\hline How often is business market research performed & $\mathbf{n}$ & $\%$ & Mean & Median & Mod \\
\hline Never & 5 & 8.1 & 2.45 & 3.00 & 3.00 \\
\hline Once a year & 24 & 38.7 & 2.45 & 3.00 & 3.00 \\
\hline Once in 6 years & 33 & 53.2 & 2.45 & 3.00 & 3.00 \\
\hline Total & 62 & 100.0 & & & \\
\hline
\end{tabular}

Examining Table 1, variables related to operational characteristics of the mean, median and mode values, the values were found close to each other. In this case, it can be said that the distribution of data is normal. We found that $58 \%$ of surveyed enterprises employed 50 people and over, $27 \%$ operated in the same sector for more than 25 years, $48 \%$ had patents between 1 and 3,95\% of R \& D investment amount was less than 5.000 . $-\mathrm{TL}, 53 \%$ of enterprises said they conducted a market research once in six months. In the following table, values of performance indicators of the surveyed enterprises for the last 5 years are given. 


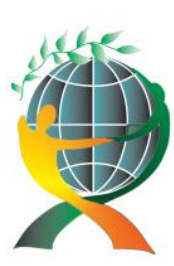

\author{
(online) $=$ ISSN $2285-3642$ \\ ISSN-L = 2285 - 3642 \\ Journal of Economic Development, Environment and People \\ Volume 3, Issue 3, 2014
}

URL: http://jedep.spiruharet.ro

e-mail: office jedep@spiruharet.ro

\begin{tabular}{|c|c|c|c|c|c|c|}
\hline $\begin{array}{l}\text { Please indicate the level of satisfaction in the last } 5 \\
\text { years for the following attributes of your business. }\end{array}$ & $\begin{array}{l}\text { Exactly } \\
\text { satisfactory }\end{array}$ & Satisfactory & Varies & $\begin{array}{l}\text { Not } \\
\text { Satisfactory }\end{array}$ & $\begin{array}{l}\text { Never } \\
\text { Satisfactory }\end{array}$ & Total \\
\hline Profit growth in shares & $\mathrm{n} / \%$ & $\mathrm{n} / \%$ & $\mathrm{n} / \%$ & $\mathrm{n} / \%$ & $\mathrm{n} / \%$ & $\mathrm{n} / \%$ \\
\hline Revenue growth & $10 / 16.1$ & $25 / 40.3$ & $\begin{array}{r}10 / 16 \\
1\end{array}$ & $11 / 17.7$ & $6 / 9.7$ & $62 / 100.0$ \\
\hline Market leadership & 9/14.5 & $31 / 50.0$ & $7 / 11.3$ & 9/14.5 & $6 / 9.7$ & $62 / 100.0$ \\
\hline Profitability per Consumer & $8 / 12.9$ & $29 / 46.8$ & $\begin{array}{r}15 / 24 \\
2\end{array}$ & $7 / 11.3$ & $3 / 4.8$ & $62 / 100.0$ \\
\hline Success rate of new products and services & $10 / 16.1$ & $24 / 38.7$ & $\begin{array}{r}17 / 27 \\
4\end{array}$ & $10 / 16.1$ & $1 / 1.6$ & $62 / 100.0$ \\
\hline Revenue from new products and services & $11 / 17.7$ & $33 / 53.2$ & $\begin{array}{r}11 / 17 . \\
7\end{array}$ & $4 / 6.5$ & $3 / 4.8$ & $62 / 100.0$ \\
\hline Investment surplus & $4 / 6.5$ & $29 / 46.8$ & $\begin{array}{r}17 / 27 \\
4\end{array}$ & $8 / 12.9$ & $4 / 6.5$ & $62 / 100.0$ \\
\hline Sales growth & $9 / 14.5$ & $23 / 37.1$ & $\begin{array}{r}16 / 25 \\
8\end{array}$ & $11 / 17.7$ & $3 / 4.8$ & $62 / 100.0$ \\
\hline Corporate reputation (image) & $16 / 25.8$ & $17 / 27.4$ & $\begin{array}{r}18 / 29 \\
0\end{array}$ & $8 / 12.9$ & $3 / 4.8$ & $62 / 100.0$ \\
\hline Growth of social assets & $24 / 38.7$ & $27 / 43.5$ & $6 / 9.7$ & $4 / 6.5$ & $1 / 1.6$ & $62 / 100.0$ \\
\hline Sales revenues & $12 / 19.4$ & $26 / 41.9$ & $\begin{aligned} 15 / 24 \\
2\end{aligned}$ & $1 / 11.3$ & $2 / 3.2$ & $62 / 100.0$ \\
\hline $\begin{array}{l}\text { Consumer products and services to meet the } \\
\text { needs of }\end{array}$ & $16 / 25.8$ & $26 / 41.9$ & $\begin{array}{r}11 / 17 . \\
7\end{array}$ & $8 / 12.9$ & $1 / 1.6$ & $62 / 100.0$ \\
\hline Ability to meet new market demands & $15 / 24.2$ & $33 / 53.2$ & $7 / 11.3$ & $5 / 8.1$ & $2 / 3.2$ & $62 / 100.0$ \\
\hline $\begin{array}{l}\text { Ability to predict potential emerging market } \\
\text { opportunities for new products and services }\end{array}$ & $19 / 30.6$ & $26 / 41.9$ & $\begin{array}{r}10 / 16 \\
1\end{array}$ & $5 / 8.1$ & $2 / 3.2$ & $62 / 100.0$ \\
\hline $\begin{array}{l}\text { Please describe the status of the last 5-year } \\
\text { market share }\end{array}$ & $16 / 25.8$ & $32 / 51.6$ & $6 / 9.7$ & $6 / 9.7$ & $2 / 3.2$ & $62 / 100.0$ \\
\hline Increased & \multicolumn{3}{|c|}{$\mathbf{n}$} & \multicolumn{3}{|c|}{$\%$} \\
\hline Unchanged & \multicolumn{3}{|c|}{43} & \multicolumn{3}{|c|}{69.4} \\
\hline Low & \multicolumn{3}{|c|}{10} & \multicolumn{3}{|c|}{16.1} \\
\hline Total & \multicolumn{3}{|c|}{9} & \multicolumn{3}{|c|}{14.5} \\
\hline Profit growth in share & \multicolumn{3}{|c|}{62} & \multicolumn{3}{|c|}{100.0} \\
\hline
\end{tabular}

When Table 2 was examined for the last 5 years, it was found that $69 \%$ of the surveyed enterprises' market shares was constantly increasing. The evaluations of the operating statuses of enterprises in the last 5 years were questioned. The evaluation revealed that $82.2 \%$ of the enterprises stated satisfaction about corporation image, $\mathbf{7 7 . 4 \%}$ about the needs of consumer products and services, and still $77.4 \%$ about activities of potential market opportunities, activities dealing with ability to predict new products and services. The aim of the study is to determine factors related to intellectual capital variables that are effective on business performance. For this purpose, factor analysis was used. The basic criteria for business performance in the factor analyses determined the market share assessments of businesses in the past 5-year. The dependent variable in the factor analysis is market share. Intellectual capital variables are independent variables in the analysis. The analysis results are provided in detail in the following section.

Descriptive Statistics for Determination of Factors Related to Intellectual Capital Variables That Affect Business Performance 


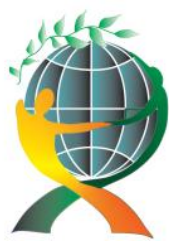

\author{
(online) $=$ ISSN $2285-3642$ \\ ISSN-L = 2285 - 3642 \\ Journal of Economic Development, Environment and People \\ Volume 3, Issue 3, 2014 \\ URL: $\underline{\text { http://jedep.spiruharet.ro }}$ \\ e-mail: office jedep@spiruharet.ro
}

In this sector, reliability in order to determine the factors formed of intellectual capital variables that influence business performance of surveyed enterprises and assessment on factor analysis was carried out. During the analysis, in determination of variables that do not represent the value required to be measured, Cronbach alpha and Item-Total Correlation (Chief, 2006:193) was used.

Intellectual capital variables which affect business performance consist of 38 sub-components relating to human capital, innovation and development, structural capital and customer capital. Cronbach alpha of these variabls was determined as $83.9 \%$. 5 variables that do not represent the common value of these variables were excluded from the analysis and the new alpha was determined as Cronbach alpha 93.3\%.

Internal reliability of the factors formed of the remaining 33 variables of intellectual capital was determined by testing their reliability respectively. The reliability of factor 1 , that consists of Innovation and Development variables found to be $88.0 \%$; the reliability of factor 2 that consists of Human capital variables is $79.0 \%$; the reliability of factor 3 that consists of structural capital variables is $83.0 \%$; and the reliability of factor 4 that consists of customer capital variables is $84.4 \%$. Also the total reliability represented by these 4-factor was calculated as $93.3 \%$.

Therefore, factors that consist of intellectual capital, effective on business performance were found to be reliable. After the reliability test, factor analysis was used to verify quantitatively the structure of factor that affects business performance.

Appropriateness of factor analysis is determined by KMO (Kaiser-Meyer-Olkin) measure of sampling adequacy. KMO is a ratio and it is desirable to be over 60\% (Nakip, 2006:429). KMO value in our study was $74.5 \%$. KMO measure of sampling adequacy was over $60 \%$. This shows that the scale of the variables is appropriate to factor analysis. The results of factor analysis are shown in Table 3.

Factor analysis was carried out using principal component analysis and the technique of varimax vertical rotation. With the help of Principal component analysis, on the bases of the factors reduction, variables are eliminated for which factor loadings are less than $33.9 \%$. In addition, values of skewness and lowness are revised in order to examine the appropriateness of normal distribution of variables which will be subjected to the factor analyses. Values were found to be approximately between -1 and +1 and the data were appropriate for normal distribution. As a result of the analysis, we found that eigen values were over 1 for four factors of which internal reliability was tested, and factor structure was quantitatively verified. Innovation and development variables describe $64.45 \%$ of the total variance in Factor 1 ; human capital variables describe $3.96 \%$ of the total variance in Factor 2; structural capital variables describe $3.33 \%$ of total variance in Factor 3 and customer capital variables describe $3.14 \%$ of the total variance in Factor 4 .

The model developed in light of the four main hypotheses was tasted. Hypothesis validity was tested using the Chi-square method. The results of the analysis are provided in the table below4. 


\section{(online) $=$ ISSN $2285-3642$ \\ ISSN-L = $2285-3642$ \\ Journal of Economic Development, Environment and People \\ Volume 3, Issue 3, 2014}

URL: http://jedep.spiruharet.ro

e-mail: office jedep@spiruharet.ro

Table 3: Arising factors in the Context of Description of Variables as a result of Factor Analysis

\begin{tabular}{|c|c|c|c|c|}
\hline & FACTÖR 1 & FACTÖR 2 & FACTÖR 3 & FACTÖR 4 \\
\hline Intellectual Capital Variables & $\begin{array}{l}\text { Innovation \& } \\
\text { Development }\end{array}$ & $\begin{array}{l}\text { Human } \\
\text { Resources }\end{array}$ & $\begin{array}{l}\text { Structural } \\
\text { Capital }\end{array}$ & $\begin{array}{c}\text { Customer } \\
\text { Capital }\end{array}$ \\
\hline s3.1.21. Intellectual assets have a useful function. & 0.710 & & & \\
\hline s3.1.18. Intellectual assets increases our capacity to work. & 0.701 & & & \\
\hline $\begin{array}{l}\text { s3.1.23. Intellectual assets are strong supporters in ensuring our competitive } \\
\text { conversion. }\end{array}$ & 0.646 & & & \\
\hline s3.1.16. Intellectual assets can help the realization of functional activities. & 0.643 & & & \\
\hline s3.1.17.Our institution acquires, quickly adapts to technological developments & 0.629 & & & \\
\hline s3.1.22. Intellectual assets can be used by companians. & 0.612 & & & \\
\hline $\begin{array}{l}\text { s3.1.14. Our institute has been increasingly investing in information } \\
\text { infrastructure(computer, internet and intranet networks, data bases) }\end{array}$ & 0.572 & & & \\
\hline $\begin{array}{l}\text { s3.1.19. There are commercial opportunities we can offer to our business } \\
\text { partners. }\end{array}$ & 0.554 & & & \\
\hline s3.1.20. Intellectual assets provide financial gains to our organization. & 0.547 & & & \\
\hline s3.1.24. We can provide resources we need from non-business sources quickly & 0.527 & & & \\
\hline $\begin{array}{l}\text { s3.1.15. IT infrastructure (computers, internet and intranet) facilitate } \\
\text { information sharing within the organization. }\end{array}$ & 0.498 & & & \\
\hline s3.1.13. Intellectual assets are difficult to imitate by competitors. & 0.358 & & & \\
\hline s3.1.10. We give importance to new ideas of our work-related employees. & & 0.709 & & \\
\hline s3.1.5. Differences in status and the status of each of our employees are defined & & 0.650 & & \\
\hline s3.1.4. Our staff has the capability to do the best jobs & & 0.618 & & \\
\hline $\begin{array}{l}\text { s3.1.8. Employees are trained and their skills are developed through programs } \\
\text { and activities such as in-house training, job rotation, delegation of authority, etc. }\end{array}$ & & 0.525 & & \\
\hline $\begin{array}{l}\text { s3.1.6. Supply qualified workers out of enterprises or other units of it, provided } \\
\text { gaining employees with new capabilities. }\end{array}$ & & 0.566 & & \\
\hline s3.1.9 In our company, a large part of our staff consists of qualified labor. & & 0.519 & & \\
\hline s3.1.2. Training expenses per employee is increasing on a regular basis. & & 0.472 & & \\
\hline s3.1.11.In order to find new ideas we look up other sources rather than business & & 0.374 & & \\
\hline s3.1.1. Our employees have the authority to control decisions about their work. & & 0.339 & & \\
\hline $\begin{array}{l}\text { S3.1.28.Company information is different from the knowledge of each } \\
\text { department. }\end{array}$ & & & 0.725 & \\
\hline $\begin{array}{l}\text { S3.1.27. Our employees are assigned to tasks that they have the appropriate } \\
\text { knowledge and qualifications. }\end{array}$ & & & 0.716 & \\
\hline $\begin{array}{l}\text { S3.1.30.Our company has a system that allows easy access to enterprise } \\
\text { information. }\end{array}$ & & & 0.670 & \\
\hline S3.1.31.Procedures are available to support innovation in our plants. & & & 0.643 & \\
\hline S3.1.29.Our company is an efficient company. & & & 0.525 & \\
\hline $\begin{array}{l}\text { S3.1.26.In-house resources (competition, environment, market, consumer } \\
\text { demands and technological change) can be adapted to changes easily. }\end{array}$ & & & 0.459 & \\
\hline s3.2.4. Loyal customer ratio is high. & & & & 0.690 \\
\hline s3.2.5. Effectiveness of communication with customers is high. & & & & 0.689 \\
\hline
\end{tabular}




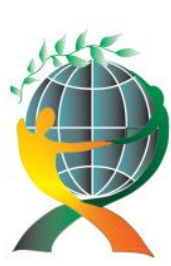

\author{
(online) $=$ ISSN $2285-3642$ \\ ISSN-L = $2285-3642$ \\ Journal of Economic Development, Environment and People \\ Volume 3, Issue 3, 2014
}

URL: http://jedep.spiruharet.ro

e-mail: office jedep@spiruharet.ro

\begin{tabular}{|l|l|r|r|} 
s3.2.2. Suppliers are visited frequently. & & 0.633 \\
\hline $\begin{array}{l}\text { s3.2.3. We are a known and recognized company in the market compared to our } \\
\text { competitors, which is an advantage for us. }\end{array}$ & & & 0.481 \\
\hline 3.2.6. The number of customers is high. & & & 0.424 \\
\hline s3.2.7. Brand name recognition is high. & & & 0.375 \\
\hline Kaiser-Meyer-Olkin Measure of Sampling Adequacy & 0.745 & \\
\hline Bartlett's Test & $\mathrm{X}^{2}=1.388 \mathrm{E} 3 \mathrm{sd}=528 \mathrm{p}=0.000$ \\
\hline
\end{tabular}

Table 4: The Relationship Between Business Performance and Intellectual Capital Variables

\begin{tabular}{|c|c|c|c|c|c|}
\hline HYPOTHESIS & & Value & $\mathrm{df}$ & $P$ & RESULT \\
\hline \multirow{2}{*}{$\begin{array}{l}\mathrm{H}_{1} \text { : As the success level of Intellectual capital effected by } \\
\text { Innovation and development increases, business performance } \\
\text { increases }\end{array}$} & Chi-square test & 10.344 & 8 & 0.02 & \multirow[b]{2}{*}{+} \\
\hline & $\begin{array}{l}\text { Chi-square Relation } \\
\text { Coefficient }\end{array}$ & 9.876 & 8 & $\begin{array}{r}0.00 \\
1\end{array}$ & \\
\hline \multirow[t]{2}{*}{$\begin{array}{l}\mathrm{H}_{2}: \text { As the success level of Intellectual capital effected by } \\
\text { Human capital increases, business performance increases. }\end{array}$} & Chi-square test & 24.204 & 8 & $\begin{array}{r}0.00 \\
2\end{array}$ & \multirow[b]{2}{*}{+} \\
\hline & $\begin{array}{l}\text { Chi-square } \\
\text { Coefficient }\end{array}$ & 19,503 & 8 & $\begin{array}{r}0.00 \\
0\end{array}$ & \\
\hline \multirow[t]{2}{*}{$\begin{array}{l}\mathrm{H}_{3}: \text { As the success level of Intellectual capital effected by } \\
\text { structural capital increases, business performance increases. }\end{array}$} & Chi-square & 21.894 & 8 & $\begin{array}{r}0.00 \\
5\end{array}$ & \multirow[t]{2}{*}{+} \\
\hline & $\begin{array}{l}\text { Chi-square Relation } \\
\text { Coefficient }\end{array}$ & 17.827 & 8 & $\begin{array}{r}0.02 \\
3\end{array}$ & \\
\hline \multirow[t]{2}{*}{$\begin{array}{l}\mathrm{H}_{4} \text { : As the success level of Intellectual capital effected by } \\
\text { customer capital increases, business performance increases. }\end{array}$} & Chi-square test & 20.666 & 8 & $\begin{array}{r}0.00 \\
8\end{array}$ & \multirow[t]{2}{*}{+} \\
\hline & $\begin{array}{l}\text { Chi-square Relation } \\
\text { Coefficient }\end{array}$ & 16.622 & 8 & $\begin{array}{r}0.02 \\
1\end{array}$ & \\
\hline
\end{tabular}

Examining Table 4, business performance positively correlated with the intellectual capital variable at 0,05 significance level. The research hypotheses is considered at $p<0,05$. The basic assumption of the study is that, the four factors formed of intellectual capital variables which effects business performance is effective on the classification according to enterprises performance levels. Which of the factors affecting business performance that have a role in discrimination has been tested with discriminant analysis? The analysis results are provided in detail in the following section.

\title{
Performance Level Discriminant Analysis
}

Discriminant analysis is one of multivariate statistical techniques, aiming to estimate the relationship between categorical dependent variables and metric independent variables. One of the aims of the discriminant analysis is to be able to determine effective and non- effective variables in distinguishing groups. For the implementation of the analysis, some assumptions must be valid. These can be expressed as: (1) variables have multiple normal distributions, (2) for all groups their covariance matrices are equal and (3) there is no direct multicollinearity problem among independent variables (Eroglu (a), 2006:335). Looking at skewness and lowness values, variables are decided to be appropriate for multiple normal 


\author{
(online) = ISSN $2285-3642$ \\ ISSN-L = $2285-3642$ \\ Journal of Economic Development, Environment and People \\ Volume 3, Issue 3, 2014 \\ URL: http://jedep.spiruharet.ro \\ e-mail: office jedep@spiruharet.ro
}

distributions. Assumptions of equality of covariance matrices for all groups were examined by using Box's $M$ test (Eroglu (a), 2006: 341). Table 4 shows the result of the test.

Table 5: Box's M Test Results

\begin{tabular}{|ll|l|}
\hline Box's M & & 15.581 \\
F & Approx. & 4.805 \\
& df1 & 3 \\
& df2 & $9.726 \mathrm{E} 3$ \\
& Sig. & 0.002 \\
\hline
\end{tabular}

Tests null hypothesis of equal population covariance matrices.

According to table 5 , at significance level $p=0,05$, Sig. was determined as 0,033 and covariance matrices were seen equal among groups. Correlation results between variables were analyzed for assumption confirmation of lack of powerful correlation among independent variables and found out that there doesn't exist a high correlation. Thus, the condition is provided for independence of factors and thanks to this, a high correlation among variables does not to exist. In order to determine the effectiveness of classification of the factors according business performance levels, enterprises are divided into binary classification such as high levels of business performance (A1) and lower performance level (A2). This classification is based on assessments of market shares of enterprises during the last 5 years. The groups' equality test, structural matrix and Fisher's discriminant function are illustrated in Table 6.

$F$ values in Table 6 at $p=0,05$ significance level indicates whether significant differences exist between enterprise groups classified according to their business performance. Accordingly, the innovation and development factors s3.1.18, intellectual assets increase our capacity to work, s3.1.14 (institute has been increasingly investing in information infrastructure (computer, internet and intranet networks, data bases)), 3.1.17 (institution acquires, quickly adapts to technological developments), s3.1.13 (intellectual assets are difficult to imitate by competitors), s3 .1.15 (IT infrastructure facilitates (computers, internet and intranet networks, data bases), information sharing within the organization); s3.1.1 from human capital factors (employees have the authority to control decisions about their work), 3.1.11 (In order to find new ideas we look up other sources rather than business), s3.1.5 (status and status of each of the differences of our employees are defined), s3.1.9 (in our company the majority of the qualified labor force consists of employees), s3.1.2 (education expense per employee is increasing on a regular basis), of structural capital factors s3.1.29 (our enterprise is an efficient enterprise), s3.1.30 (easy access to enterprise information system that allows easy access to features), s3.1.31 (There are procedures that support our business innovation), s3.1.26 (In-house resources (competition, environment, market, consumer demands and technological change) can be adapted to changes easily.), s3.1.28 (company information is different from the knowledge of each department), customer capital s3.2.4 factors (high percentage of loyal customers), s3.2.2 (Suppliers are visited often), s3.2.6 (higher number of customers) from the businesses participating in the survey, significant differences in terms of performance levels were found $(p<0,05)$. 


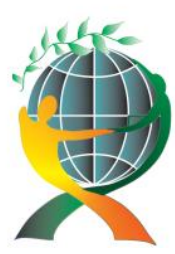

\author{
(online) $=$ ISSN $2285-3642$ \\ ISSN-L = 2285 - 3642 \\ Journal of Economic Development, Environment and People \\ Volume 3, Issue 3, 2014
}

URL: http://jedep.spiruharet.ro

e-mail: office jedep@spiruharet.ro

Table 6: The Groups' Equality Test, Structural Matrix and Fisher's Discriminant Function

\begin{tabular}{|l|l|l|l|l|l|l|l|l|}
\hline Variable & Wilks $\lambda$ & F & Sd1 & Sd2 & $p$ & $\begin{array}{l}\text { Structural } \\
\text { Matrix }\end{array}$ & $\begin{array}{l}\text { Y1 } \\
\text { (High) }\end{array}$ & $\begin{array}{l}\text { Y2 } \\
\text { (Low) }\end{array}$ \\
\hline Factor 1 & & & & & & & & \\
\hline s3.1.18 & 0.844 & 6.095 & 1 & 51 & 0.019 & 0.576 & 1.574 & 0.258 \\
\hline s3.1.14 & 0.738 & 6.924 & 1 & 51 & 0.003 & 0.412 & 2.294 & 0.700 \\
\hline s3.1.17 & 0.705 & 12.981 & 1 & 51 & 0.001 & 0.530 & 2.269 & 1.006 \\
\hline s3.1.13 & 0.547 & 8.061 & 1 & 51 & 0.000 & 0.236 & 5.622 & 2.086 \\
\hline s3.1.15 & 0.334 & 13.948 & 1 & 51 & 0.001 & 0.359 & 4.467 & 2.791 \\
\hline Factor 2 & & & & & & & & \\
\hline s3.1.1 & 0.913 & 4.663 & 1 & 51 & 0.036 & 0.696 & 2.319 & 1.537 \\
\hline s3.1.11 & 0.863 & 4.771 & 1 & 51 & 0.037 & 0.276 & 2.544 & 1.681 \\
\hline s3.1.5 & 0.809 & 5.322 & 1 & 51 & 0.008 & 0.533 & 2.661 & 1.908 \\
\hline s3.1.9 & 0.725 & 6.192 & 1 & 51 & 0.005 & 0.110 & 3.617 & 2.536 \\
\hline s3.1.2 & 0.483 & 10.351 & 1 & 51 & 0.000 & 0.303 & 5.397 & 3.671 \\
\hline Factor 3 & & & & & & & & \\
\hline s3.1.29 & 0.854 & 8.696 & 1 & 51 & 0.003 & 0.671 & 6.336 & 3.555 \\
\hline s3.1.30 & 0.836 & 4.710 & 1 & 51 & 0.014 & 0.562 & 2.887 & 3.772 \\
\hline s3.1.31 & 0.788 & 6.732 & 1 & 51 & 0.001 & 0.116 & 1.279 & 1.033 \\
\hline s3.1.26 & 0.780 & 10.385 & 1 & 51 & 0.005 & 0.649 & 2.878 & 1.276 \\
\hline s3.1.28 & 0.763 & 11.828 & 1 & 51 & 0.001 & 0.774 & 5.083 & 2.327 \\
\hline Factor 4 & & & & & & & & \\
\hline s3.2.4 & 0.898 & 3.971 & 1 & 51 & 0.054 & 0.528 & 2.226 & 0.243 \\
\hline s3.2.2 & 0.643 & 5.749 & 1 & 51 & 0.003 & 0.303 & 2.069 & 0.961 \\
\hline s3.2.6 & 0.396 & 10.673 & 1 & 51 & 0.000 & 0.282 & 12.521 & 8.512 \\
\hline (Constant) & & & & & & & -36.022 & -16.851 \\
\hline & & & & & & \\
\hline
\end{tabular}

Building matrix expresses correlation between discriminant function and discriminant variables (Akgül and Çevik, 2003:414).

Factor 3 composed of discriminant function, was generated according to performance level in structural matrix, and intellectual capital variables. Variables related to Factor $3,(s 3.1 .28(0,774))$ are seen to have the highest correlation coefficient among them.

In addition, the coefficients relating to Factor 1 composed of variables of innovation and development, Factor 2 composed of human capital variables, and Factor 3 composed of customer variables, are the other significant coefficients in the structure matrix. In discrimination of business groups according to their performance levels, among the variables related to Factor1, Factor2, Factor 3, and Factor4, those that take place in Table 5 appear to be decisive.

Columns $\mathrm{Y} 1$ and $\mathrm{Y} 2$ in Table 5, show Fisher's discriminant function coefficients. Fisher linear discriminant function coefficients enable the evaluation of the importance of the independent variables (Eroglu (b), 2006:342). The Y1 column shows the high level of performance, the Y2 column shows the coefficients of the enterprises with low levels of performance. These coefficients describe how independent variables contribute to separate the groups (Morales and Fernandez, 2004). The large coefficients indicate high contribution; small coefficients indicate a low contribution in the columns Y1 and 


\author{
(online) $=$ ISSN $2285-3642$ \\ ISSN-L = 2285 - 3642 \\ Journal of Economic Development, Environment and People \\ Volume 3, Issue 3, 2014 \\ URL: http://jedep.spiruharet.ro \\ e-mail: office jedep@spiruharet.ro
}

Y2. Coefficients related to variables of the 4 factors in columns Y1 and Y2 are positive and statistically significant.

According to this, for the business groups with high level of performance, variables relating to the 4 factors in Table 5 contribute highly. For businesses with low levels of performance, these factors contribute lowly.

\begin{tabular}{|l|l|l|l|l|l|l|}
\hline Functions & Eigen values & canonical correlation & Wilks $\lambda$ & $X^{2}$ & sd & $p$ \\
\hline 1 & 1.407 & 0.538 & 0.771 & 11.607 & 2 & 0.003 \\
\hline
\end{tabular}

According to Eigen values and Wilks $\lambda$ Values (Level Of Performance Of Enterprises), property of eigen values is greater than 1 which indicates that the differential feature of the discriminant function is "good". However, canonical correlation explains $100 \%$ of the total variance of coefficient and $53.8 \%$ of intergroup difference. Canonical correlation is 0,538. It may imply that the function is a good discriminator of intergroup separation. Also Wilks $\lambda(0,771)$ analysis by the value of $X 22$ degrees of latitude, was statistically significant $(X 2=11.607, p<0,001)$. In Table 7 the results of the classification are made according to the level of performance.

Table 7: Classification Results (business performance levels)

\begin{tabular}{|l|l|l|l|}
\hline \multirow{2}{*}{ Real Group Membership } & \multicolumn{2}{|c|}{ Estimated Group Membership } & \multirow{2}{*}{ Total } \\
\cline { 2 - 4 } & Y1(high) & Y2(low) & \\
\hline G1 & 36 & 7 & 43 \\
\hline$\%$ & 83.7 & 16.3 & 100.0 \\
\hline G2 & 8 & 11 & 19 \\
\hline$\%$ & 42.1 & 57.8 & 100.0 \\
\hline
\end{tabular}

\title{
Correct Classification Rate of $81.1 \%$
}

In Table 7 according to the level of performance classification, $83.7 \%$ of the 43 enterprises with high level of performance and $57.8 \%$ of the 19 enterprises with low levels of performance are correctly assigned. High correct classification rate is considered as an indicator of success of the analysis (Akgül and Çevik, 2003:415). The Discriminant function's weighted average rate of correct classification was found to be $81.1 \%$. These results are sufficient for distinctive features of discriminant function.

\section{Results and Evaluations}

Today global markets demonstrate rapid development and intense competition. For this reason enterprises especially SMEs which comprise $99.89 \%$ of all business in our country, will be able to increase business performance by creating value through relationship with intellectual assets already existing among non-tangible values such as human resources, brands, customers, and marketing channels. Consumers and customers are placed at the focal point of basic activities of businesses. That is why it is necessary to evaluate intellectual capital expressed as common brain power and knowledge, with regard to business performance intellectual capital components and business performance in small and medium-sized enterprises. 


\author{
(online) = ISSN $2285-3642$ \\ ISSN-L = $2285-3642$ \\ Journal of Economic Development, Environment and People \\ Volume 3, Issue 3, 2014 \\ URL: $\underline{\text { http://jedep.spiruharet.ro }}$ \\ e-mail: office jedep@spiruharet.ro
}

A survey questionnaire prepared within the scope of this aim was applied in 130 enterprises operating in Çorum and 62 valid ones were analyzed statistically. The analysis revealed that, in consideration of the number of employees of businesses participating in our investigation, $73 \%$ of them employed under 250 staff, which is in line with the nature of SMEs.

As a result of the research, we found that $98.4 \%$ of enterprises are under 25 years old, $40 \%$ of them have no patents and $48 \%$ of them have between 1-3 patents. It can be said that amounts of R\&D expenditure of enterprises is not sufficient. $94 \%$ of enterprises who invest on $R \& D$, have been spending under 5,000.-TL (Nearly 2,500.- $€$ ) in this area. This expenditure is quite inadequate.

Analyzing within the framework of factors, four factors appear in studying the activities of enterprises on intellectual capital. These factors express $75 \%$ level of impact of intellectual capital of business on business performance. Factor 1 which is formed of innovation and development variables explains $64.45 \%$ of the total variance; factor 2 which is formed of human capital variables $3.96 \%$, factor 3 which is formed of structural capital variables $3.33 \%$, and factor 4 which is formed of customer capital variables indicates $3.14 \%$ of the total variance.

As a result of the tests of the hypotheses developed within the scope of research models, we found out the existence of a positive relation among the activity level and innovation concepts of the intellectual capital components and business performance, at $p<0,005$ level.

In short, the synergy which is formed by intellectual capital components of small and medium-sized enterprises has a direct impact on enterprises' performance. In very aggravate and hard competitive conditions, SMEs need to invest on intellectual capital elements in order to sustain their existence effectively. Enterprises that do not invest on components of intellectual capital will lose their current status day by day, even if they manage to continue their existence.

\title{
5. References
}

[1] JA. Akgül ve Çevik O., İstatistiksel Analiz Teknikleri SPSS' te İşletme Yönetimi Uygulamaları, Emek Ofset, Ankara, 2003

[2] R. Amit, P.J.H. Schoemaker, Strategic Assets And Organizational Rent. Strategic Management Journal, 1993, 14: 33-46.

[3] D. Andriessen, IC Valuation and Measurement: Classifying the State Of The Art, Journal Of Intellectual Capital, 2004, 5(2): 230-242.

[4] J.B. Barney, Organizational Culture: Can It Be A Source Of Sustained Competitive Advantage?. Academy Of Management Review, 1986, 11(3): 656-665.

[5] Baş, Türker, (2006); Anket Nasıl Hazırlanır? Anket Nasıl Uygulanır?, Anket Nasıl Değerlendirilir?, Ankara, Şeçkin YayıneviNakip, Mahir. (2006). Pazarlama Araştırmaları. Ankara: Seçkin Kitabevi.

[6] N. Bontis, W. Keov, S. Richardson, Intellectual Capital and The Nature Of Business In Malaysia, Journal Of Intellectual Capital, 2000, I(1): 85-100.

[7] A. Brooking, Intellectual Capital: Core Assets For The Third Millennium Enterprise. London: Thompson Business Pres, 1996

[8] Brown Jr Andrew, Twila Osborn, James M Chan, Venkat Jaganathan (), Managing Intellectual Capital, Research 


\author{
(online) $=$ ISSN $2285-3642$ \\ ISSN-L = $2285-3642$ \\ Journal of Economic Development, Environment and People \\ Volume 3, Issue 3, 2014 \\ URL: http://jedep.spiruharet.ro \\ e-mail: office jedep@spiruharet.ro
}

Technology Management, Nov/Dec, 2005, 48, (6): 34-41.

[9] W. Cohen, D. Levinthal, Absorptive Capacity: A New Perspective on Learning and Innovation, Administrative Science Quarterly, March, vii-xvi. (1990),

[10] P. F Drucker, The Information Executives Truly Need, Harward Business Rewiev, 1995.

[11] L. Edvinsson, Developing Intellectual Capital at Skandia, Long Range Planning, 1997, 30, (3):366-373.

[12] L. Edvinsson, M.S. Malone, Intellectual Capital: Realizing Your Company's True Value By Finding Its Hidden Brainpower. New York: Harper Business, 1997

[13] Erkal, Zekeriya Intellectual Capital Measurement and Reporting, Deep Publications. (2006);

[14] Eroglu, Abdullah (a), Factor Analysis, SPSS Applied Multivariate Statistical Techniques, Editors: Kalaycı, Honor, Ankara: Master Release Distribution. (2006);

[15] Eroğlu, Abdullah (b), "Diskrimnant Analysis", SPSS Applied Multivariate Statistical Techniques, Editors: Kalaycl, Honor, Ankara: Master Release Distribution, 2006.

[16] C.M. Fiol, Managing Culture as a Competitive Resource: An Identity-Based View Of Sustainable Competitive Advantage, Journal Of Management, 1991, 17: 191-211.

[17] R. Hall, The Strategic Analysis Of Intangible Resources, Strategic Management Journal, 1992, 13, 135-144.

[18] C. Handy, Inside Organisations Twenty One Ideas for Managers, Penguin Business. 1990

[19] Itami, Roehl, Mobilizing Invisible Assets, Mass.:Harvard Business Review. 1987

[20] Kanıbir H., "Yeni Bir Rekabet Gücü Kaynağı Olarak Entelektüel Sermaye ve Organizasyonel Performansa Yansımaları", Havacılık ve Uzay Teknolojileri Dergisi, Cilt: 1 Sayı: 3, 2004.

[21] D.J. Knight, Performance Measures For Increasing Intellectual Capital, Strategy \& Leadership, 1999, 29, (1), $22-28$.

[22] A.A. Lado, M.C. Wilson, Human Resource Systems And Sustained Competitive Advantage: A Competency-Based Perspective. Academy Of Management Journal, 1994, 19(4), 699-727.

[23] F.J. Mata, W.L. Fuerst, J.B. Barney, Information Technology And Sustained Competitive Advantage: A ResourceBased Analysis. MIS Quarterly, 1995, 19, 487-505.

[24] Yun Ji Moon, H.G. Kym, A Model for the Value of Intellectual Capital, Canadian Journal of Administrative Sciences, Sep. 2006, 23(3), 253-269.

[25] F. X.M. Morales, ve M.M.T Fernandez, How much difference is there between industrial district firms? A net value creation approach, Research Policy, 2004, 33, 473-486.

[26] Pirtini, Serdar, Marketing Management from the Perspective of Intellectual Capital, Prentice Hall International, Ankara, 2004

[27] M. Porter, Competitive Strategy. New York: Free Press, 1980.

[28] Powell, T.C. (1997), "Information Technology As Competitive Advantage: The Role Of Human, Business, And Technology Resources". Strategic Managemet Journal, 18, 375-405.

[29] G. Roos, J. Roos, Measuring Your Company's Intellectual Performance, Long Range Planning, 1997, 30(3), 413-426.

[30] Rose, Ian, Valuing Intellectual Capital. Summary Report: IBR Consulting Services Ltd., March, 2000, 17, 5.

[31] H. Saint-Onge, Tacit Knowledge: The Key to The Strategic Alignment Of Intellectual Capital, Strategy\&Leadership, 


\author{
(online) $=$ ISSN $2285-3642$ \\ ISSN-L = 2285 - 3642 \\ Journal of Economic Development, Environment and People \\ Volume 3, Issue 3, 2014 \\ URL: http://jedep.spiruharet.ro \\ e-mail: office jedep@spiruharet.ro
}

1996, 24, (2), 10-14.

[32] T. A Stewart, Brainpower, Fortune, 1991, 127:44-66.

[33] T. A. Stewart, Your Company's Most Valuable Asset: Intellectual Capital, Fortune, 1994, 130, (7):28-33.

[34] T. A. Stewart, Intellectual Capital the New Wealth Of Organizations. New York: Bantam Doubleday Dell Publishing Group, Inc, 1997.

[35] K.E. Sveiby, Intellectual Capital: The New Wealth of Organizations. New York: Doubley/Currency, 1997.

[36] B. Wernerfelt, A Resource Based View Of The Firm, Strategic Management Journal, 1984, 5(2), 171-180.

[37] YILDIZ B. Ve B. Tenekecioğlu, Intellectual Capital Impact on Business and Market Value of Property in the ISE-100 Empirical Study ", 3rd National Knowledge, Economy and Management Congress (Eskişehir), 2004, 579-590.

[38] Yu, K. Peter, From Pirates to Partners: Protecting Intellectual Property in China in the Twenty-First Century, Cordozo Public Law Research Paper No. 34, Amecian University Law Review, 2001, 50, 131-243.

[39] U. Zander, B. Kogut, Knowledge And The Speed Of The Transfer And Imitation Of Organizational Capabilities: An Empirical Test. Organization Science, 1995, 6(1), 76-92. 